BOLETIN LATINOAMERICANO Y DEL CARIBE DE PLANTAS MEDICINALES Y AROMÁTICAS 19 (6): 591 - 600 (2020)

ㄷ / ISSN 07177917 / www.blacpma.ms-editions.cl

\title{
Articulo Original / Original Article \\ Impact of Kuntai Capsules on LIF, IGF-1 and EGF expression in the implantation window of endometrium in mice
}

\author{
[Impacto de cápsulas de Kuntai en la expresión de LIF, IGF-1 y EGF en la ventana de \\ implantación de endometrio en ratones] \\ Li Tan ${ }^{1}$, Xiao-Xu Li ${ }^{2}$, Xi-Ying Chu', Yan Li ${ }^{1} \&$ Li-Jing Wan' \\ ${ }^{1}$ Reproductive Medical Center, the 2nd Affiliated Hospital of Zhengzhou University, Zhengzhou, China \\ ${ }^{2}$ Department of Gynecology and Obstetrics, Traditional Chinese Medical Hospital of Zhengzhou, Zhengzhou, China \\ Contactos | Contacts: Li TAN - E-mail address: li_cx902@163.com
}

\begin{abstract}
To investigate the influence of Kuntai capsules on the expression level of leukemia inhibitory factor (LIF), insulin-like growth factor-I (IGF-1) and epidermal growth factor (EGF) during the mouse's implantation window of superovulation period and controlled ovarian hyperstimulation period. 90 female mice were randomly divided into six groups in control, superovulation and controlled ovarian hyperstimulation $(\mathrm{COH})$ conditions. The RNA expression of EGF, LIF and IGF-1 in the endometrium on the 4th day of pregnancy was detected, and the relative expression was compared. mRNA expression of these three factors in endometrium was significantly lower in superovulation and $\mathrm{COH}$ groups than control group $(p<0.001)$. mRNA expression of these three factors in endometrium remained obviously lower in superovulation plus kuntai capsule group and $\mathrm{COH}$ plus kuntai capsule group than control group $(p<0.01)$. mRNA expression of these three factors in endometrium was lower in control group than in the NS plus kuntai capsule group ( $p<0.05)$. Kuntai capsule cannot completely reverse the endometrial damages caused by superovulation and COH. Thus Kuntai capsule could partially improve a mouse's endometrial receptivity during the implantation window.
\end{abstract}

Keywords: Kuntai capsules; Controlled ovarian hyperstimulation; Leukaemia inhibitory factor; Insulin-like growth factor I; Epidermal growth factor

Resumen: Para investigar la influencia de las cápsulas de Kuntai en el nivel de expresión del factor inhibidor de la leucemia (LIF), el factor de crecimiento similar a la insulina I (IGF-1) y el factor de crecimiento epidérmico (EGF) durante la ventana de implantación del ratón del período de superovulación y la hiperestimulación ovárica controlada período, se dividieron aleatoriamente 90 ratones hembra en seis grupos en condiciones de control, superovulación e hiperestimulación ovárica controlada (COH). Se detectó la expresión de ARN de EGF, LIF e IGF-1 en el endometrio al cuarto día de embarazo, y se comparó la expresión relativa. La expresión de ARNm de estos tres factores en el endometrio fue significativamente menor en los grupos de superovulación y COH que en el grupo control $(p<0,001)$. La expresión de ARNm de estos tres factores en el endometrio permaneció más baja en el grupo de cápsulas de superovulación más Kuntai y en el grupo de cápsulas de $\mathrm{COH}$ más Kuntai respecto del grupo control $(p<0,01)$. La expresión de ARNm de estos tres factores en el endometrio fue menor en el grupo control que en el grupo de cápsula NS más Kuntai $(p<0,05)$. La cápsula de Kuntai no pudo revertir completamente los daños endometriales causados por la superovulación y la $\mathrm{COH}$. Por lo tanto, se sugiere que la cápsula de Kuntai podría mejorar parcialmente la receptividad endometrial de un ratón durante la ventana de implantación.

Palabras clave: Triatoma cápsulas de Kuntai; Hiperestimulación ovárica controlada; Factor inhibidor de leucemia; Factor de crecimiento similar a la insulina I; Factor de crecimiento epidérmico

Recibido | Received: November 12, 2019

Aceptado | Accepted: April 6, 2020

Aceptado en versión corregida | Accepted in revised form: April 17, 2020

Publicado en línea | Published online: November 30, 2020

Este artículo puede ser citado como / This article must be cited as: L Tan, XX Li, XY Chu, Y Li, LJ Wan. 2020. Impact of Kuntai Capsules on LIF, IGF-1 and EGF expression in the implantation window of endometrium in mice. Bol Latinoam Caribe Plant Med Aromat 19 (6): 591 - 600. https://doi.org/10.37360/blacpma.20.19.6.42 


\section{INTRODUCTION}

Along with social development and economic growth, the number of people with infertility continues to increase year by year due to a variety of factors, including the worsening air pollution, heightened life stress, and obesity (Aliyeh \& Laya, 2007; Gies, 2012; Broughton \& Moley, 2017; Ding et al., 2017]. Against this background, Assisted Reproductive Technology (ART) has gradually caught the attention of infertility patients. Although ART has been around for over 30 years, it has not yet gained popularity due to low clinical pregnancy rate (Rhodes et al., 2005; Yang et al., 2015). According to relevant literatures, $60 \%$ of all failures of in vitro fertilization-embryo transfers (IVF-ETs) are attributed to diminished endometrial receptivity (Moreno \& Franasiak, 2017). Therefore, the key for increasing embryo implantation rate and clinical pregnancy rate is to improve endometrial receptivity. Endometrial tolerance refers to the endometrium's capability to receive embryos, which is crucial for a successful embryonic implantation (Yang et al., 2019). The endometrial process of embryonic implantation and development is completed within a short period of time, which is called the implantation window or nidation window (Yang et al., 2019). Numerous studies have confirmed that the establishment of endometrial tolerance during the implantation window is mediated through the concerted effects of multiple cytokines (Kuhla, 2020). For example, IFN- $\gamma$, TNF- $\alpha$ and IL-2 secreted by Th 1 cells can cause cytotoxic effects during cellular immunity process, thus it detrimental to endometrial tolerance, while Th 2 cells can help to build up immune tolerance, thus is helpful to endometrial tolerance (Taylor \& Sasser, 2017).

Multiple studies have shown that leukemia inhibitory factor (LIF), insulin-like growth factor-I (IGF-1), and epidermal growth factor (EGF) exhibit high expression levels during the implantation window of several different species of mammals (Islam et al., 2016; Pathare et al., 2017). In addition, the concerted effects of these factors contribute to the establishment of endometrial tolerance. Therefore, these cytokines are generally considered as markers for testing endometrial tolerance. However, the drugs commonly used to improve endometrium tolerance are still subject to a variety of problems. For example, pilot studies indicated that low-dose aspirin (Madani et al., 2019) or aromatase inhibitors (Khayat et al., 2019) could improve implantation, but sample sizes were too small and larger studies are needed to prove it, thus it remains questionable whether aspirin and aromatase inhibitors can actually improve the rate of embryo implantation. The price of growth hormone is too high, and Chinese medicine has the disadvantage of patient compliance. In order to overcome these problems, there is a need to determine a safe, convenient and inexpensive drug that could improve endometrial receptivity.

Kuntai capsules have been applied to improve female ovarian function in clinic for several years. It is a formulated traditional Chinese medicine that comprise of six herb components: Rehmannia glutinosa as the primary ingredient, Radix Paeoniae Alba, Coptis chinensis and donkey-hide gelatin as the secondary ingredients, and Scutellaria baicalensis and Poria cocos as the adjuvant ingredients (Zhou et al., 2016). And it has been discovered that Kuntai capsules may be effective for treating menopausal syndrome and has few adverse effects (Zhou et al., 2016). It has been reported that endometrial thickness (Chu et al., 2014) and endometrial receptivity (Wu, 2015) can be improved. In the present study, quantitative fluorescence PCR (QF-PCR) was used to analyze the effects of Kuntai capsules on the expression levels of three cytokines related to endometrial tolerance during the superovulation cycle, natural cycle and controlled ovarian hyperstimulation mice implantation stage, providing a theoretical basis for the clinical application of ART, improving a patient's endometrial tolerance, and improving the clinical pregnancy rate. Mice were randomly divided into six groups to explore the effects of Kuntai capsules in control, superovulation and controlled ovarian hyperstimulation $(\mathrm{COH})$ conditions.

\section{MATERIALS AND METHODS General materials}

Healthy clean-grade 8-10-week-old Kunming (KM) mice (20-30 grams in body weight) were chosen for the present study. Mice housing conditions are as follows: room temperature, $18-25^{\circ} \mathrm{C}$; humidity, $60 \%$ $70 \%$; 12-hour illumination followed by 12-hour darkness; male and female mice are kept in separate cages; mice were given unlimited access to food and water. Female mice that appeared normal in two successive estrous cycles were used in the experiments. All mice were purchased from the Laboratory Animal Center of Zhengzhou University (Permit \#: SCXK[Henan] 2010-0002).

Trizol buffer solution was purchased from Gibco (America). 50 bp DNA Ladder was purchased from Tiangen Biotech (MD108-01. Beijing). Total RNA extraction kit for fresh animal tissues and cells 
was purchased from Novland (LN-0108A, Shanghai). Universal Reverse Transcription Kit was purchased from Novland (LR-0103A, Shanghai). ComSYBR qPCR Mix (with Rox) was purchased from Novland (LK-0107BB, Shanghai). Kuntai capsule was purchased from Xintian Medicine (Guiyang). Pregnant mare serum gonadotropin (PMSG) was purchased from Biosun Biotechnology (Shanghai). Triptorelin acetate for injection (GnRHa) was purchased from Ferring (Germany). Human chorionic gonadotropin (HCG) was purchased from (Livzon Medicine, Zhuhai).

Kuntai capsule is a formulated traditional Chinese medicine that comprise of six herb components: Rehmannia glutinosa as the primary ingredient, Radix Paeoniae Alba, Coptis chinensis and donkey-hide gelatin as the secondary ingredients, and Scutellaria baicalensis and Poria cocos as the adjuvant ingredients.

This study is approved by the Laboratory Animal Welfare and Ethical Committee of our institution.

\section{Technique for observing the estrous cycles of mice}

For judging the estrous cycle of female mice, vaginal smears were obtained at 9 AM every day with medical cotton swabs for morphology observation and the classification of the shedding of vaginal cells. The specific operation procedures were as follows: The tail was lifted with the left hand to fully expose the vaginal orifice. Then, the features of the external genital were observed, a medical cotton swab predipped in physiological saline solution was held with the right hand and inserted it into the mouse' vagina at $0.5 \mathrm{~cm}$ in depth. Next, the swab was slowly twirled, pulled out, and the secretion stuck on the swab was smeared on a glass slide. Then, the slide was place on the bench for one minute, fix in $95 \%$ ethanol for 15-20 minutes, and hematoxylin and eosin (H\&E) staining was performed (hematoxylin for one minute, eosin for 50 seconds). The slide was washed with distilled water, dried out, and observed under a microscope to ascertain the cell morphology. The mice estrous cycle can be divided into four phases, according to the features of the external genitals and vaginal smears of mice: proestrus, estrus, metestrus, and anestrus.

\section{Experiment group and modeling}

Female mice with two successive normal estrous cycles are divided into six groups, with 15 mice in each group: control group, saline solution plus Kuntai capsule group, superovulation group, superovulation plus Kuntai capsule group, controlled ovarian hyperstimulation $(\mathrm{COH})$ group, and $\mathrm{COH}$ plus Kuntai capsule group. The animal model was established as described below.

(1) Control group: At 9 AM every day, $0.3 \mathrm{ml}$ of saline solution was applied on each mouse via intraperitoneal injection for nine days in succession. At the $9^{\text {th }}$ day, an extra saline solution was injected at $0.3 \mathrm{ml}$ per mouse. After 48 hours, $0.3 \mathrm{ml}$ was applied per mouse via intraperitoneal injection. Each female mouse was paired one-on-one with a male after ovulation. The appearance of the vaginal plug was check at $6 \mathrm{AM}$ of the next day. Mice with a vaginal plug was marked as pregnancy day one and feed with $0.3 \mathrm{ml}$ of saline solution per day until euthanization.

(2) Saline solution plus Kuntai capsule group: At 9 AM every day, $0.3 \mathrm{ml}$ of saline solution was applied per mouse via intraperitoneal injection for nine days in succession. At the $9^{\text {th }}$ day, extra saline solution was injected at $0.3 \mathrm{ml}$ per mouse. After 48 hours, $0.3 \mathrm{~mL}$ was applied per mouse via intraperitoneal injection. Each female mouse was paired one-on-one with a male after ovulation. The appearance of the vaginal plug was check at $6 \mathrm{AM}$ of the next day. Mice with a vaginal plug was marked as pregnancy day one and feed with $90.1 \mathrm{mg} / 100 \mathrm{~g}$ of body weight of solution of Kuntai capsule powder per day until euthanization.

(3) Superovulation group: At 9 AM every day, $0.3 \mathrm{ml}$ of saline solution was applied per mouse via intraperitoneal injection for nine days in succession. At the $9^{\text {th }}$ day, 10 IU of PMSG was injected per mouse. After 48 hours, 10 IU of HCG was applied per mouse via intraperitoneal injection. Each female mouse was paired one-on-one with a male during the evening. The appearance of the vaginal plug was checked at 6 AM of the next day. Mice with a vaginal plug were marked as pregnancy day one and fed with $0.3 \mathrm{ml}$ of saline solution per day until euthanization.

(4) Superovulation plus Kuntai capsule group: At 9 AM every day, $0.3 \mathrm{ml}$ of saline solution was applied per mouse via intraperitoneal injection for nine days in succession. At the $9^{\text {th }}$ day, $10 \mathrm{IU}$ of PMSG was injected per mouse. After 48 hours, $10 \mathrm{IU}$ of HCG was applied per mouse via intraperitoneal injection. Each female mouse was paired one-on-one with a male during the evening. The appearance of the vaginal plug was checked at $6 \mathrm{AM}$ of the next day. Mice with a vaginal plug was marked as pregnancy day one, and feed with $90.1 \mathrm{mg} / 100 \mathrm{~g}$ of body weight of solution of KUNTAI Capsule powder per day until euthanization. 
(5) $\mathrm{COH}$ group: At the beginning of metestrus, $1.5 \mathrm{ug} / 100$ grams of body weight of GnRHa was applied per mouse at 9 AM everyday via intraperitoneal injection for nine days in succession. At the $9^{\text {th }}$ day, 10 IU of PMSF was injected per mouse. After 48 hours, 10 IU of HCG was applied per mouse via intraperitoneal injection. Each female mouse was paired one-on-one with a male during the evening. The appearance of the vaginal plug was checked at $6 \mathrm{AM}$ of the next day. Mice with a vaginal plug was marked as pregnancy day one and feed with $0.3 \mathrm{ml}$ of saline solution per day until euthanization.

(6) $\mathrm{COH}$ plus Kuntai capsule group: At the beginning of metestrus, $1.5 \mathrm{ug} / 100$ grams of body weight of GnRHa was applied per mouse at 9 AM everyday via intraperitoneal injection for nine days in succession. At the $9^{\text {th }}$ day, 10 IU of PMSF was injected per mouse. After 48 hours, $10 \mathrm{IU}$ of HCG was applied per mouse via intraperitoneal injection. Each female mouse was paired one-on-one with a male during the evening. The appearance of the vaginal plug was checked at $6 \mathrm{AM}$ of the next day. Mice with a vaginal plug were marked as pregnancy day one and fed with $90.1 \mathrm{mg} / 100 \mathrm{~g}$ of body weight of solution of Kuntai capsule powder per day until euthanization.

At 9 AM of the fourth day after pregnancy, anesthetics were applied to all mice via intraperitoneal injection. Caesarean section was performed to remove the uterus. A piece of endometrial tissue was slice off from the uterus on ice and weighed on an electronic scale. The tissue was immediately transferred to a centrifuge tube with $1 \mathrm{ml}$ of Trizol lysis buffer. An electronic homogenizer was used to homogenize the tissues for 15 seconds in an ice-bath, and the tissue sample was stored in a freezer at $-80^{\circ} \mathrm{C}$.

\section{Detection method of quantitative fluorescence PCR (QF-PCR)}

Following the manual of the Trizol reagent, total RNA was extracted from mice endometrial tissues and reverse-transcribed into cDNA. The reactions were set up on ice. The system of the reverse transcription were RT Master Mix $(2 \times)$ at $10 \mu \mathrm{L} / \mathrm{L}$, RT Enzyme Mix at $1 \mu \mathrm{L} / \mathrm{L}$, Oligo (dT) Random at 1 $\mu \mathrm{L} / \mathrm{L}$, specific primer $(1 \mu \mathrm{M})$ at $1.2 \mu \mathrm{L} / \mathrm{L}, \quad$ RNA template at $5-8 \mu \mathrm{L} / \mathrm{L}$, RNase Free $\mathrm{ddH}_{2} \mathrm{O}$, and total reaction at $20 \mu$. The conditions of the reversetranscription were $45^{\circ} \mathrm{C}$ for 40 minutes, and $85^{\circ} \mathrm{C}$ for 10 minutes.

LIF, IGF-1, EGF and $\beta$-actin (internal control) are amplified using cDNA reversetranscribed from RNA as the template. The full DNA sequences of LIF, IGF-1, EGF and $\beta$-actin were obtained by searching the Genbank (Table No. 1).

Table No. 1

Primer Sequence

\begin{tabular}{|c|c|c|c|}
\hline Label & Sequence & Tm value & Amplified Fragment \\
\hline \multirow[t]{2}{*}{ LIF } & 5'CATTTCCTATTACACAGCTCAAGGG3' & 60 & $74 \mathrm{bp}$ \\
\hline & 5'GTCTGTCATGTTAGGCGCACATAG3' & & \\
\hline \multirow[t]{2}{*}{ IGF-1 } & 5'TGACCGCACCTGCAATAAAGATAC3' & 60 & $103 b p$ \\
\hline & 5'TCTGGTCCAGCTGTGGTGGAG3' & & \\
\hline \multirow[t]{2}{*}{ EGF } & 5'TAACGGGACAGGACTAGAGAAAGTG3' & 60 & $115 b p$ \\
\hline & 5'GGTGATGACTCCGTTCTGTTGG3' & & \\
\hline \multirow[t]{2}{*}{$\beta$ - actin } & 5'AAGATCAAGATCATTGCTCCTCC3' & 60 & $119 \mathrm{bp}$ \\
\hline & 5'GACTCATCGTACTCCTGCTTGC3' & & \\
\hline
\end{tabular}

The reaction composition were cDNA template at $\mathrm{X} \mu \mathrm{L}$, forward primer $(5 \mu \mathrm{M})$ at $0.4 \mu \mathrm{L}$, reverse primer $(5 \mu \mathrm{M})$ at $0.4 \mu \mathrm{L}$, PCR Master Mix $(2 \times)$ at $10 \mu \mathrm{L}, \mathrm{ddH}_{2} \mathrm{O}$, and total reaction at $20 \mu$. The conditions were $94^{\circ} \mathrm{C}$ for two minutes, $94^{\circ} \mathrm{C}$ for 15 seconds, and $62^{\circ} \mathrm{C}$ for 40 seconds, for a total of 40 cycles.

When analyzing the fluorescence intensities of each sample with QF-PCR, the relative quantitative $\triangle \triangle \mathrm{CT}$ method was used to detect changes

Boletín Latinoamericano y del Caribe de Plantas Medicinales y Aromáticas/594 
in gene expression. Before the $\triangle \Delta \mathrm{CT}$ test, a pilot experiment was performed to validate its feasibility. An easy dilution was used to prepare serial dilutions of one sample cDNA $(1 \times, 10 \times, 100 \times, 1,000 \times$, $10,000 \times)$. QF-PCR assay was conducted on these dilutions with $\beta$-actin as the internal control. The $\triangle \triangle \mathrm{CT}$ was only applicable if it was under the same reaction composition and conditions, the difference between the amplification curve slopes of the target gene and internal control was $<0.1$ (Livak \&
Schmittgen, 2001).

\section{Statistical analysis}

All data were processed using SPSS 17.0. The quantitative comparison of inter-group data was achieved using $t$-test. Univariate analysis was used for quantitative comparisons between multiple sets of data. LSD $t$-test was applied to achieve one-on-one comparisons among multiple sets of data. A $P$-value $<0.05$ was considered statistically significant.

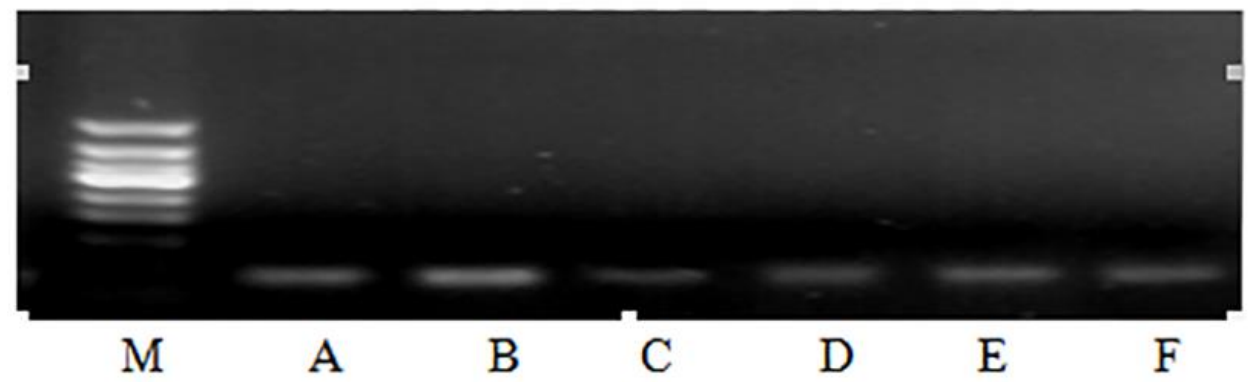

Figure No. 1

The electrophoresis results of LIF in group A F. The M lane is 500 BP DNA ladder, and A-F lanes are the results of LIF protein electrophoresis in A-F group

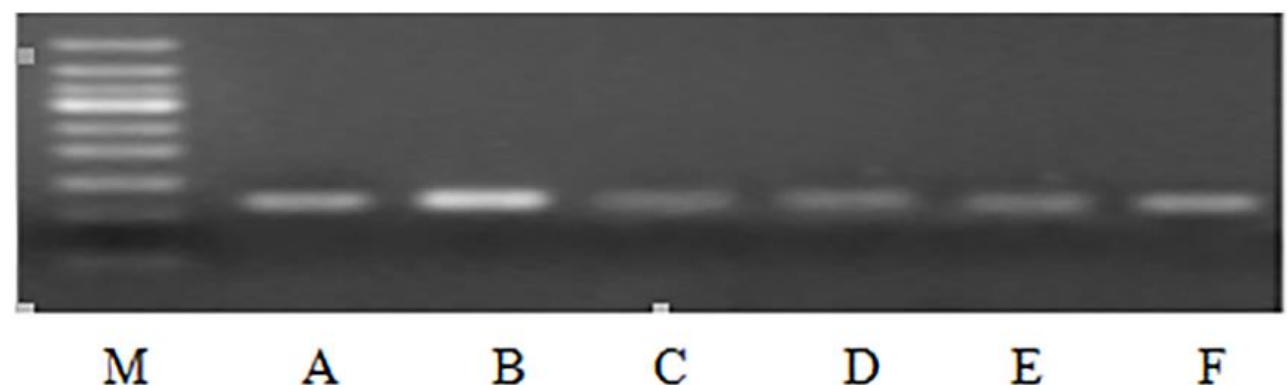

Figure No. 2

The electrophoresis results of IGF-1 in group A F. The M lane is 500 BP DNA ladder, and A-F lanes are then results of IGF-1 protein electrophoresis in A-F group

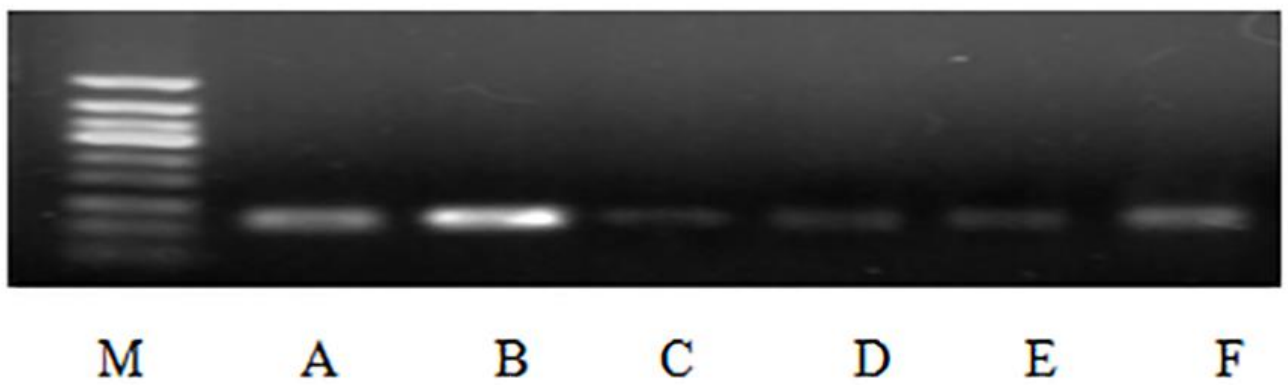

Figure No. 3

The electrophoresis results of EGF in group A F. The M lane is 500 BP DNA ladder, and A-F lanes are the results of IGF-1 protein electrophoresis in A-F group) 


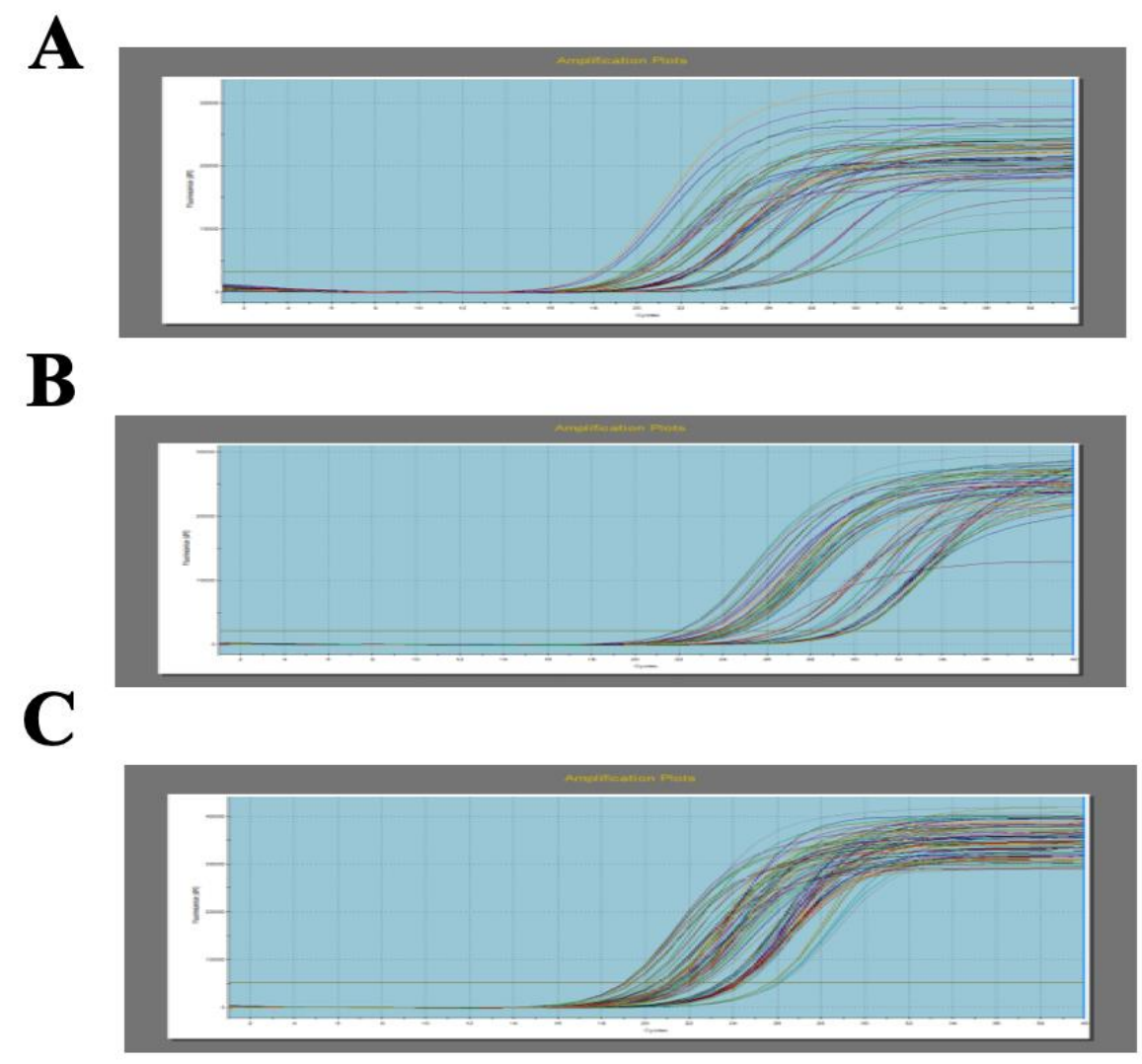

Figure No. 4

Amplification curve of LIF (A), IGF-1 (B), EGF (C).

\section{RESULTS}

Electrophoresis results of LIF, IGF-1 and EGF in all groups

Electrophoresis results of LIF, IGF-1 and EGF in all groups are shown in Figure No. 1, Figure No. 2, and Figure No. 3, respectively. Melting curves are shown in Figure No. 4

The expression levels of LIF, IGF-1 and EGF in the different groups

The expression of LIF, IGF-1 and EGF in mouse entrometrial tissues in the control group and saline solution plus Kuntai capsules group

The mRNA levels of LIF, IGF-1 and EGF were high in endometrial tissues in the control group and saline solution plus Kuntai capsule group at the implantation window phase. QF-PCR results also suggest that all three genes exhibited higher expression levels in the saline solution plus Kuntai capsules group than in the control group. The differences were statistically significant, as suggested by the mean $p$-value $(<0.001)$ (Figure No. 5).
The expression of LIF, IGF-1 and EGF in murine entrometrial tissues in the superovulation group and superovulation plus Kuntai capsule group

The mRNA levels of LIF, IGF-1 and EGF were low in endometrial tissues in the superovulation group and superovulation plus Kuntai capsule group at the implantation window phase. However, QF-PCR results also suggest that all three genes exhibited higher expression levels in the superovulation plus Kuntai capsule group than in the superovulation group. The differences were statistically significant, as suggested by the mean $p$-value $(<0.001)$ (Figure No. 5).

The expression of LIF, IGF-1 and EGF in murine entrometrial tissues in the $\mathrm{COH}$ group and $\mathrm{COH}$ plus Kuntai capsule group

The mRNA levels of LIF, IGF-1 and EGF were low in endometrial tissues in the $\mathrm{COH}$ group, while medium levels were observed in samples obtained 
from the $\mathrm{COH}$ plus Kuntai capsule group. QF-PCR results suggest that all three genes exhibited higher expression levels in the $\mathrm{COH}$ plus Kuntai capsule group than in the $\mathrm{COH}$ group. The differences were statistically significant, as suggested by the mean $p$ value $(<0.001)$ (Figure No. 5).
$\mathbf{A}$

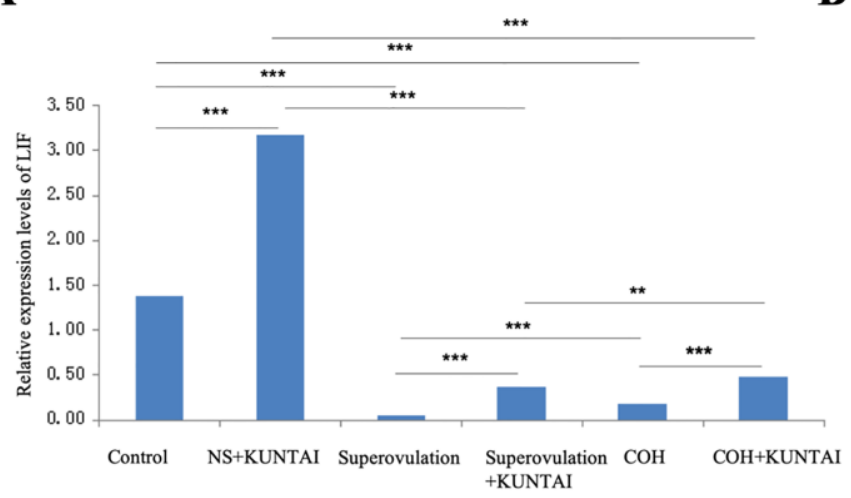

B

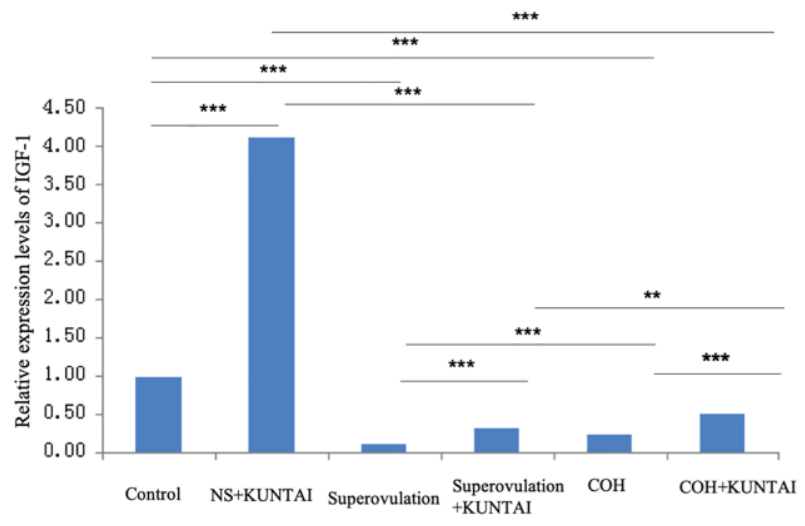

C

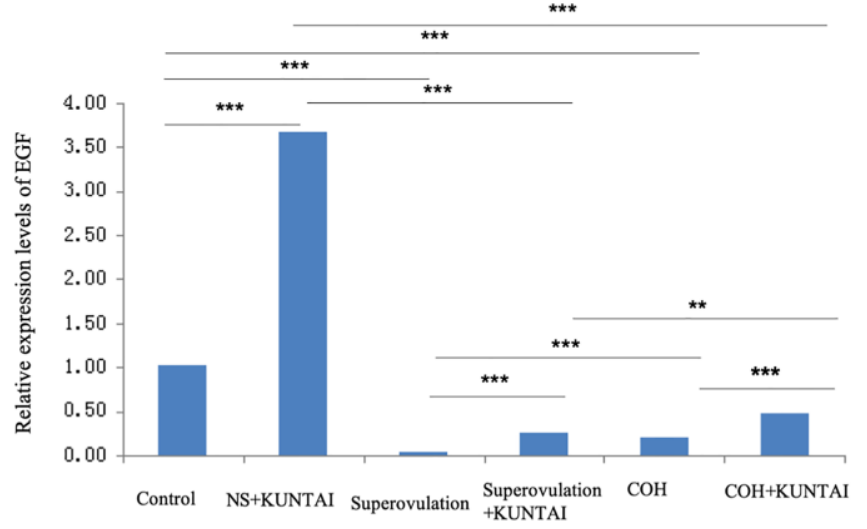

Figure No. 5

Relative mRNA expression of LIF, IGF-1, EGF in each group. ${ }^{* *}, p<0.01 ; * * *, p<0.001$

Effects of superovulation and $\mathrm{COH}$ on the expression levels of LIF, IGF-1 and EGF in murine endometrial tissues

The mRNA levels of LIF, IGF-1 and EGF were significantly higher in the control group than in the superovulation group (mean $p$-value $<0.001$ ) and $\mathrm{COH}$ group, and the differences were statistically significant (mean $p$-value $<0.001$ ). Moreover, these levels in the $\mathrm{COH}$ group were higher than in the superovulation group, and the differences were also statistically significant (mean $p$-value $<0.001$ ) (Figure No. 5).
Effects of Kuntai capsules on the expression levels of LIF, IGF-1 and EGF in murine endometrial tissues

The mRNA levels of LIF, IGF-1 and EGF in the control group were markedly higher than in the superovulation plus Kuntai capsule group and $\mathrm{COH}$ plus Kuntai capsule group, and the differences were statistically significant, as suggested by mean $p$ values $<0.001$. In addition, all three genes exhibited a higher mRNA expression in the $\mathrm{COH}$ plus Kuntai capsule group than in the superovulation plus Kuntai capsule group, and the difference was statistically significant (mean $p$-value $<0.01$ ) (Table No. 2). 
Table No. 2

The relative mRNA expression levels of three cytokines in control group, Superovulation+KUNTAI group and $\mathrm{COH}+\mathrm{KUNTAI}$ group with group $A$ as the reference

\begin{tabular}{llccc}
\hline Group & Group Size & LIF & IGF-1 & EGF \\
\hline Control Group & 15 & 1.00 & 1.00 & 1.00 \\
Superovulation+KUNTAI Group & 15 & 0.27 & 0.34 & 0.26 \\
COH+KUNTAI Group & 15 & 0.35 & 0.52 & 0.47 \\
\hline
\end{tabular}

\section{DISCUSSION}

As the most representative ones among these cytokines, LIF, IGF-1 and EGF play crucial roles in regulating endometrial tolerance. As a means to promote the simultaneous development of multiple follicles, superovulation and $\mathrm{COH}$ have become an important part of ART therapy. Nonetheless, according to related studies (Chillik \& Acosta, 2001; Meyer et al., 2019), superovulation and $\mathrm{COH}$ may disrupt the synchrony between embryonic development and the opening of the implantation window, which would lead to diminished endometrial tolerance and in vitro fertilization (IVF) pregnancy rate. Therefore, we need to identify a therapeutic strategy that could minimize the impact of superovulation on endometrial tolerance.

Medicines presently used for this purpose include low-dose aspirin, aromatase inhibitor, growth hormone and Chinese Medicines such as donkey-hide gelatin. However, the actual efficacy of aspirin and aromatase inhibitor in improving embryonic implantation and clinical pregnancy remains controversial. The usage of growth hormone is limited due to its high cost, whereas Chinese medicine has a number of drawbacks such as inconvenient intake and poor patient adherence. In order to overcome these challenges, there is a need to seek for a safe, convenient and inexpensive medicine that could improve endometrial tolerance. Kuntai capsule is a formulated traditional Chinese medicine that comprise of six herb components: Rehmannia glutinosa as the primary ingredient, Radix Paeoniae Alba, Coptis chinensis and donkey-hide gelatin as the secondary ingredients, and Scutellaria baicalensis and Poria cocos as the adjuvant ingredients. By maintaining the Yin and Yang balance, it is supposed to achieve the efficacies of supplementing the kidney, nurturing the liver, nourishing the Yin and dousing body flames, and soothing the nerves. Multiple studies (Zhang et al., 2005; Huang et al., 2008; Wang, 2010) have suggested that Chinese medicine for nourishing the kidney and invigorating blood circulation could improve the blood circulation of the endometrim to a certain extent. By promoting blood supply to endometrium and increasing endometrium thickness and the number of glands, such medicines can help increase the clinical pregnancy rate.

Results of the present study revealed that the mRNA expression levels of the three cytokines are markedly higher in the saline solution plus Kuntai capsules group than in the control group. Moreover, these expression levels were higher in the superovulation plus Kuntai capsule group and $\mathrm{COH}$ plus Kuntai capsule group, compared to the superovulation group and $\mathrm{COH}$ group, indicating the efficacy of Kuntai capsules in improving murine endometrial tolerance. Nonetheless, based on the univariate analysis of the mRNA levels of these three cytokines in the control group, superovulation plus Kuntai capsule group and $\mathrm{COH}$ plus Kuntai capsule group, the control group exhibited the highest levels, followed by the superovulation plus Kuntai capsule group and $\mathrm{COH}$ plus Kuntai capsule group. This indicates that despite the positive effect of Kuntai capsules on murine endometrial tolerance, it is insufficient to offset damages to the endometrium induced by superovulation and $\mathrm{COH}$. Chu et al. (2013) evaluated the effects of Kuntai capsules on murine endometrial thickness through immunohistochemistry and demonstrated that Kuntai capsules can significantly enhance the endometrial protein levels of LIF and IGF-1. Moreover, they revealed that these levels were significantly higher in the superovulation plus Kuntai capsule group and $\mathrm{COH}$ plus Kuntai capsule group, compared to the superovulation group and $\mathrm{COH}$ group. Another study (Wang et al., 2012) demonstrated that high doses of Kuntai capsules did not display early embryonic toxicity to SD rats, and does not affect the reproductivity of rats, suggesting of the superb safety of Kuntai capsules in clinical application. Thus, in our future work, we may consider increasing the dosage of Kuntai capsule or combining it with other medicines, with the hope of finding a more ideal drug 
that could neutralize endometrial damages caused by superovulation and $\mathrm{COH}$, and increase the clinical pregnancy rate of IVF-ET.

Currently, there's no consensus on which composition of Kuntai capsule contributes to endometrial tolerance the most. Based on the literature, it may be assumed that the primary ingredient Rehmannia glutinosa could exert protective effects on the embryo impanation, and Radix Paeoniae Alba, Coptis chinensis and donkeyhide gelatin can strengthen the effect of Rehmannia glutinosa (Chu et al., 2014). However, more studies are needed to clarify the mechanisms.
In summary, the application of Chinese medicine Kuntai capsule in IVF-ET can partially improve murine endometrial tolerance by increasing the expression of three relevant cytokines during the implantation window. However, it is insufficient to completely reverse the endometrial damages caused by superovulation and $\mathrm{COH}$. In the present study, only conventional doses of Kuntai capsule power solutions were tested. Since previous studies have demonstrated the safety of large doses of Kuntai capsules, we can identify the maximum remedial effect of Kuntai capsules on damaged endometrial tolerance in the future, providing reliable experimental evidences for further clinical research.

\section{REFERENCES}

Aliyeh G, Laya F. 2007. Quality of life and its correlates among a group of infertile Iranian women. Med Sci Monit 13: $313-317$.

Broughton DE, Moley KH. 2017. Obesity and female infertility: potential mediators of obesity's Impact. Fertil Steril 107: 840 - 847. https://doi.org/10.1016/j.fertnstert.2017.01.017

Chillik C, Acosta A. 2001. The role of LHRH agonists and antagonists. Reprod Biomed Online 2: 120 - 128. https://doi.org/10.1016/s1472-6483(10)62236-5

Chu X, Song Y, Wan L, Tan L. 2014. Effects of kuntai capsule on endometrial thickness and the expression of epidermal growth factor proteins in the uterus of control superovulation mice. Zhonghua Yi Xue Za Zhi 94: $2300-2303$

Chu XY. 2013. The effects of Chinese Medicine KUNTAI Capsule on endometrial thickness, EGF, IGF-1, PCNA and LIF protein levels during murine reproductive phase. Thesis, Zhenzhou University, China.

Ding J, Luo XT, Yao YR, Xiao HM, Guo MQ. 2017. Investigation of changes in endocannabinoids and Nacylethanolamides in biofluids, and their correlations with female infertility. J Chromatogr A 1509: 16 25. https://doi.org/10.1016/j.chroma.2017.06.029

Islam MR, Yamagami K, Yoshii Y, Yamauchi N. 2016. Growth factor induced proliferation, migration, and lumen formation of rat endometrial epithelial cells in vitro. J Reprod Dev 62: 271 - 278. https://doi.org/10.1262/jrd.2015-158

Gies E. 2012. Even conscientious people have an eco-footprint. Earth Island J 27: 51 - 52.

Livak KJ, Schmittgen TD. 2001. Analysis of relative gene expression data using real-time quantitative PCR and the 2(-Delta DeltaC(T)) method. Methods 25: 402 - 408. https://doi.org/10.1006/meth.2001.1262

Huang DM, Huang GY, Lu FE. 2008. Impacts on blastocyst implantation dysfunction and murine endometrial glands apoptosis by Chinese medicines for nourishing kidney, soothing nerves and improving blood circulation. J Trad Chin Med 49: 644 - 646.

Madani T, Ahmadi F, Jahangiri N, Bahmanabadi A, Bagheri Lankarani N. 2019. Does low-dose aspirin improve pregnancy rate in women undergoing frozen-thawed embryo transfer cycle? A pilot double-blind, randomized placebo-controlled trial. J Obstet Gynaecol Res 45: 156 - 163.

https://doi.org/10.1111/jog.13802

Meyer WR, Novotny DB, Fritz MA, Beyler SA, Wolf LJ, Lessey BA. 1999. Effect of exogenous on endometrial maturation in oocyte donors. Fertil Steril 71: 109 - 114. https://doi.org/10.1016/s0015-0282(98)00390-2

Moreno I, Franasiak JM. 2017. Endometrial microbiota - new player in town. Fertil Steril 108: 32 - 39. https://doi.org/10.1016/j.fertnstert.2017.05.034

Khayat S, Elliott B, Dahan MH. 2019. Management of recurrent implantation failure by gonadotropin-releasing hormone agonist and aromatase inhibitor suppression, in women without evidence of endometriosis. Gynecol Endocrinol 35: 267 - 270. https://doi.org/10.1080/09513590.2018.1519790

Kuhla B. 2020. Review: Pro-inflammatory cytokines and hypothalamic inflammation: implications for insufficient feed intake of transition dairy cows. Animal 14: s65 - s77. https://doi.org/10.1017/s1751731119003124

Pathare ADS, Zaveri K, Hinduja I. 2017. Downregulation of genes related to immune and inflammatory response in 
IVF implantation failure cases under controlled ovarian stimulation. Am J Reprod Immunol 78: e12679. https://doi.org/10.1111/aji.12679

Rhodes TL, McCoy TP, Higdon HL 3rd, Boone WR. 2005. Factors affecting assisted reproductive technology (ART) pregnancy rates: a multivariate analysis. J Assist Reprod Genet 22: 335 - 346. https://doi.org/10.1007/s10815-005-6794-1

Taylor EB, Sasser JM. 2017. Natural killer cells and T lymphocytes in pregnancy and pre-eclampsia. Clin Sci 131: 2911 - 2917. https://doi.org/10.1042/cs20171070

Wang W, Zhang Y, Liu K, Gong HY, He JL, Gong L. 2012. Study on impacts on SD rats' reproductivity and early embryonic toxicity of KUNTAI Capsule. Chin Trad Patent Med 34: 1869 - 1873

Wang WJ. 2010. Clinical and experimental studies on treating embryonic implantation failures with Chinese medicines for nourishing kidney and limbs. Thesis, Hubei University of Chinese Medicine, China.

Wu CJ. 2015. Effects of kuntai capsule on follicular development, endometrium and ovulation in ovulatory infertility. China Practical Med 18: 10 - 11.

Yang R, Yang S, Li R, Chen X, Wang H, Ma C, Liu P, Qiao J. 2015. Biochemical pregnancy and spontaneous abortion in first IVF cycles are negative predictors for subsequent cycles: an over 10,000 cases cohort study. Arch Gynecol Obstet 292: 453 - 458. https://doi.org/10.1007/s00404-015-3639-8

Yang X, Gilman-Sachs A, Kwak-Kim J. 2019. Ovarian and endometrial immunity during the ovarian cycle. J Reprod Immunol 133: 7 - 14. https://doi.org/10.1016/j.jri.2019.04.001

Zhang SC, Wu ZK, Cai LX, Shen MX. 2005. Theoretic significance of "promoting sexuality through nurturing kidney" based on the experimental evidences for improving effects of kidney nourishing Chinese medicine on tissue angiogenesis. Study J Trad Chin Med 23: 1078 - 1080.

Zhou Q, Tao J, Song H, Chen A, Yang H, Zuo M, Li H. 2016. Chinese herbal medicine Kuntai capsule for treatment of menopausal syndrome: a systematic review of randomized clinical trials. Complement Ther Med 29: 63 - 71. https://doi.org/10.1016/j.ctim.2016.09.011 